\title{
Faktor-Faktor yang Mempengaruhi Prestasi Belajar Mahasiswa Tingkat 1 Universitas Pamulang Fakultas Ekonomi Program Studi Manajemen Reguler A.
}

\author{
Derita Qurbani ${ }^{1}$, Ibrahim Bali Pamungkas ${ }^{2}$, Sewaka ${ }^{3}$ \\ ${ }^{1,3)}$ Universitas Pamulang email : dosen01582@unpam.ac.id
}

\section{ARTICLES \\ INFORMATION}

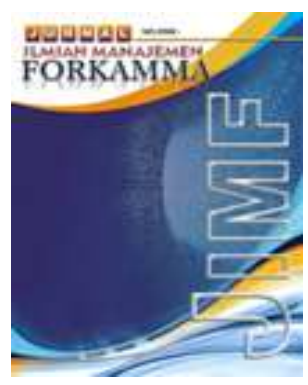

\section{JURNAL ILMIAH MANAJEMEN FORKAMMA}

\author{
Vol.3, No.3, Juli 2020 \\ Halaman : $205-226$ \\ (C) LPPM \& FORKAMMA \\ Prodi Magister Manajemen \\ UNVERSITAS PAMULANG
}

ISSN (online) : 2599-171X

ISSN (print) : : 2598-9545

\section{Keyword :}

Learning Motivation; Learning Interest; Physical Healt; Academic Advisor; Social Circle; Learning Achievement.

JEL. classification : O15,

Contact Author :

\section{PRODI}

\section{MAGISTER MANAJEMEN \& FORKAMMA UNPAM}

JL.Surya Kencana No.1 Pamulang

Tangerang Selatan - Banten

Telp. (021) 7412566, Fax (021) 7412491 Email :

jurnalforkamma.unpam@gmail.com
ABSTRACT
Pendidikan pada hakekatnya bertujuan untuk membentuk sumber daya manusia seutuhnya yang berkualitas. Kualitas pendidikan erat kaitannya dengan proses pembelajaran karena proses pembelajaran merupakan salah satu segi terpenting dalam bidang pendidikan. Selain adanya anggapan tersebut prestasi belajar mahasiswa juga dipengaruhi faktor-faktor lain.Metode yang digunakan dalam penelitian ini kuantitatif. Data diambil dari hasil kuesioner. Analisis data dilakukan dengan mengunakan 4 (empat) tahapan yaitu pengumpulan data, validitas item, penyajian data dan penarikan kesimpulan. Berdasarkan hasil penelitian menunjukkan bahwa, Terdapat pengaruh positif dan signifikan secara secara simultan antara Motivasi Belajar $\left(X_{1}\right)$, Minat Belajar $\left(X_{2}\right)$, Kesehatan Jasmani $\left(X_{3}\right)$, Pembimbing Akademik $\left(X_{4}\right)$, dan Lingkungan Sosial $\left(X_{5}\right)$ Terhadap Prestasi Belajar (Y) dan yang paling dominan adalah faktor motivasi belajar dengan presentase sebesar 46,3\%.

Education is essentially aimed at forming quality human resources as a whole. The quality of education is closely related to the learning process because the learning process is one of the most important aspects in the field of education. TIn addition to these assumptions, student learning achievements are also influenced by other factors. The method used in this study is quantitative. Data is taken from the results of the questionnaire. Data analysis was performed using 4 (four) stages, namely data collection, item validity, data presentation and conclusion. Based on the results of the study indicate that, there is a positive and significant effect simultaneously between Learning Motivation (X1), Learning Interest (X2), Physical Health (X3), Academic Advisors (X4), and Social Environment (X5) Against Learning Achievement ( $Y$ ) and the most dominant is the learning motivation factor with a percentage of $46.3 \%$. 


\section{A. PENDAHULUAN}

Pendidikan pada dasarnya adalah untuk membentuk kualitas di seluruh aset manusia. Kualitas pengajaran benar-benar menantang dengan persiapan pembelajaran karena proses pembelajaran adalah salah satu sudut paling penting pada bidang pengajaran. Pendidikan adalah salah satu kunci untuk maju, cara yang lebih berkualitas dalam pengajaran dipegang penuh oleh negara. Di Indonesia, pengajaran sangat penting, karena pengajaran adalah bagian yang sangat penting dalam mewujudkan peradaban nasional yang terhormat. Bagaimanapun, pengajaran di Indonesia masih memiliki banyak masalah, banyak komponen yang dapat mempengaruhi masalah pengajaran di Indonesia terkait dengan kualitas pendidikan, modul dan pendekatan pendidikan. Salah satu masalah dengan pengajaran di Indonesia adalah kualitas pengajaran yang kurang baik.

Untuk tercapainya tujuan tersebut, maka harus melalui proses pendidikan formal dan non-formal. Pendidikan formal dapat diatur dan jalur pengajaran berlapis yang terdiri dari pendidikan dasar, pendidikan menengah, pengajaran tambahan senior dan pengajaran yang lebih tinggi. Sedangkan pengajaran non-formal dapat menjadi cara pengajaran di luar pengajaran formal yang dapat diaktualisasikan secara terorganisir dan berlapis. Pengajaran non-formal mencakup pengajaran anak usia dini, pengajaran kemampuan hidup, pendidikan kursus, persiapan pendidikan dan pertemuan umat Islam, serta unit pengajaran yang sebanding.

"Pendidikan dikatakan berkualitas bila proses belajar mengajar dapat berjalan dengan lancar, efektif, efisien dan ada interaksi antara komponen-komponen yang terkandung dalam sistem pengajaran yaitu tujuan pendidikan dan pengajaran, peserta didik atau mahasiswa, tenaga kependidikan atau guru, kurikulum, strategi pembelajaran, media pengajaran dan evaluasi pengajaran" (Hamalik, 2008).

Sesuai dengan Undang-Undang Nomor 20 Tahun 2003 tentang sistem Pendidikan Nasional bahwa "Pendidikan Nasional bertujuan mengembangkan potensi peserta didik agar menjadi manusia yang beriman dan bertaqwa kepada Tuhan Yang Maha Esa, berakhlak mulia, sehat, berilmu, cakap, kreatif, mandiri, dan menjadi warga negara yang demokratis dan peka terhadap tantangan zaman. Tujuan pendidikan merupakan tujuan yang hendak dicapai melalui upaya pendidikan secara menyeluruh. Tujuan pendidikan ini merupakan tujuan bersama yang telah ditetapkan oleh pemerintah dan tertera dalam Garis-garis Besar Haluan Negara (GBHN)".

Untuk negara Berkembang, pengajaran dipandang sebagai perangkat efektif terpenting untuk perencanaan staf yang berbakat dan siap di semua bidang kemajuan. Karakter yang memiliki makna jika didukung oleh keahlian. Oleh karena itu manusia adalah sumber paling untuk kemajuan negara. Pengajaran bisa menjadi fenomena manusia mendasar yang juga mencakup sifat membantu dalam kehidupan manusia. Bagi orang, pengajaran mungkin suatu keharusan, karena pengajaran manusia akan memiliki kapasitas dan identitas untuk diciptakan.

Bentuk kesuksesan belajar di sekolah dapat dilihat berdasarkan prestasi belajar, karena prestasi belajar menampilkan hasil usaha yang dicapai mahasiswa selama mereka melakukan pembelajaran di perguruan tinggi yang pada umumnya ditunjukan dalam bentuk IPK. Sesuai dengan ketentuan kurikulum yang berlaku untuk mengukur keberhasilan pembelajaran yaitu dengan ditetapkannya batas minimum 3,25 (tiga koma dua lima) untuk skala kampus swasta. Atas dasar ketentuan ini diharapkan mahasiswa dapat mencapai hasil yang optimal.

Atas dasar tersebut di atas peneliti mencoba observasi yang dilakukan kepada 40 mahasiswa secara acak di tingkat pertama Fakultas Ekonomi Jurusan Manajemen Reguler A sebelum melakukan penelitian lebih lanjut, berikut data hasil observasi : 
Tabel 1.1 Hasil Observasi Mahasiswa

\begin{tabular}{|c|c|c|}
\hline Jenis Kelamin & Usia & IPK \\
\hline Perempuan & 18 & 3.63 \\
\hline Laki-laki & 19 & 2.79 \\
\hline Laki-laki & 20 & 3.79 \\
\hline Perempuan & 19 & 3.32 \\
\hline Laki-laki & 19 & 2.95 \\
\hline Perempuan & 18 & 3.5 \\
\hline Perempuan & 18 & 3.42 \\
\hline Perempuan & 19 & 3.2 \\
\hline Perempuan & 19 & 3.89 \\
\hline Perempuan & 19 & 2.6 \\
\hline Perempuan & 20 & 3.56 \\
\hline Perempuan & 18 & 3 \\
\hline Perempuan & 18 & 3.37 \\
\hline Perempuan & 19 & 3.4 \\
\hline Laki-laki & 22 & 2.37 \\
\hline Perempuan & 20 & 3.63 \\
\hline Perempuan & 21 & 3.74 \\
\hline Laki-laki & 18 & 3.32 \\
\hline Laki-laki & 19 & 3.75 \\
\hline Perempuan & 19 & 3.4 \\
\hline Perempuan & 20 & 3.89 \\
\hline Perempuan & 19 & 3.26 \\
\hline Perempuan & 20 & 3.89 \\
\hline Perempuan & 19 & 3.84 \\
\hline Perempuan & 18 & 4 \\
\hline Laki-laki & 18 & 3.68 \\
\hline Perempuan & 18 & 3.79 \\
\hline Laki-laki & 19 & 3.4 \\
\hline Perempuan & 19 & 3.5 \\
\hline Laki-laki & 18 & 3.16 \\
\hline Perempuan & 18 & 3.89 \\
\hline Perempuan & 18 & 3.89 \\
\hline Laki-laki & 21 & 3.05 \\
\hline Laki-laki & 19 & 3.26 \\
\hline Perempuan & 18 & 3.74 \\
\hline Perempuan & 17 & 4 \\
\hline Perempuan & 18 & 3.79 \\
\hline Laki-laki & 19 & 2.74 \\
\hline Perempuan & 20 & 3.63 \\
\hline Laki-laki & 20 & 3.1 \\
\hline
\end{tabular}




\section{Sumber : Hasil Observasi 2019}

Dari data di atas dapat di jelaskan, berdasarkan hasil observasi terhadap 40 mahasiswa secara acak di dapatkan jenis kelamin 13 Laki-laki dan 27 Perempuan, dan, dengan rentang usia antara 18 sampai 21 , dan IPK yang berjumlan di bawah 3,25 sebanyak 10 orang. Berdasarkan tabel 1.1 membuktikan bahwa kemampuan mahasiswa Fakultas Ekonomi Jurusan Manajemen Reguler A telah memenuhi kriteria ketuntasan minimum. Prestasi belajar yang sudah baik ini terjadi karena mahasiswa konsep-konsep dan materi kuliah dan juga mereka berpikiran lulus tepat waktu. Adanya anggapan kuliah di Universitas Pamulang cukup menyenangkan turut memicu prestasi belajar mahasiswa sehingga menjadi baik. Selain adanya anggapan tersebut prestasi belajar mahasiswa juga dipengaruhi faktor-faktor lain. Faktor-faktor lain yang ikut berpengaruh terhadap prestasi belajar dibedakan menjadi dua yaitu faktor intrinsik atau yang berasal dari dalam diri manusia yang terdiri dari motivasi belajar, minat belajar, kesehatan jasmani dan faktor ekstrinsik atau yang berasal dari luar diri manusia yang terdiri dari pembimbing akademik dan lingkungan sosial.

\section{B. KAJIAN LITERATUR}

\section{A. Prestasi Belajar}

\section{Pengertian Prestasi Belajar}

Hasil belajar yang diperoleh siswa diukur berdasarkan perbedaan tingkah laku sebelum dan sesudah belajar dilakukan. Pengertian yang lebih umum mengenai prestasi belajar ini dikemukakan oleh Moh. Surya (2004), yaitu "prestasi belajar adalah hasil belajar atau perubahan tingkah laku yang menyangkut ilmu pengetahuan, keterampilan dan sikap setelah melalui proses tertentu, sebagai hasil pengalaman individu dalam interaksi dengan lingkungannya".

\section{Indikator Prestasi Belajar}

Menurut Muhibbin Syah (2008) "Pengungkapan hasil belajar meliputi segala ranah psikologis yang berubah sebagai akibat pengalaman dan proses belajar siswa". Namun demikian pengungkapan perubahan tingkah laku seluruh ranah, khususnya ranah afektif sangat sulit. Hal ini disebabkan perubahan hasil belajar itu ada yang bersifat intangible (tidak dapat diraba). Di bawah ini adalah tabel yang menunjukan jenis, indikator dan cara evaluasi belajar:

Tabel 2.1 Jenis, Indikator dan Cara Evaluasi

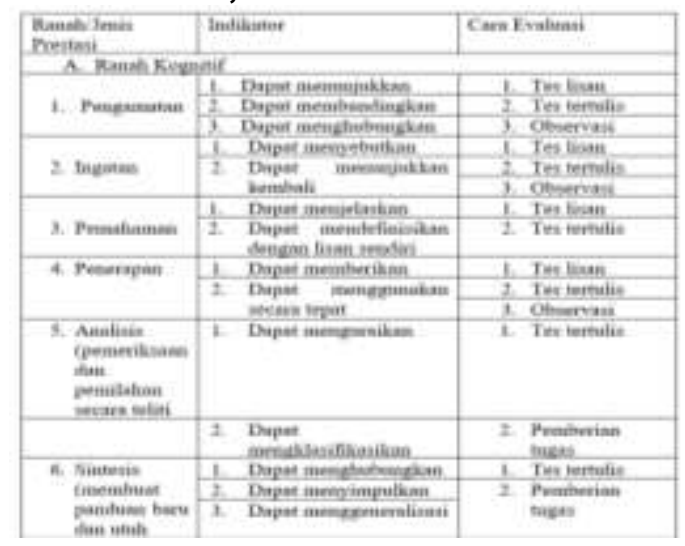




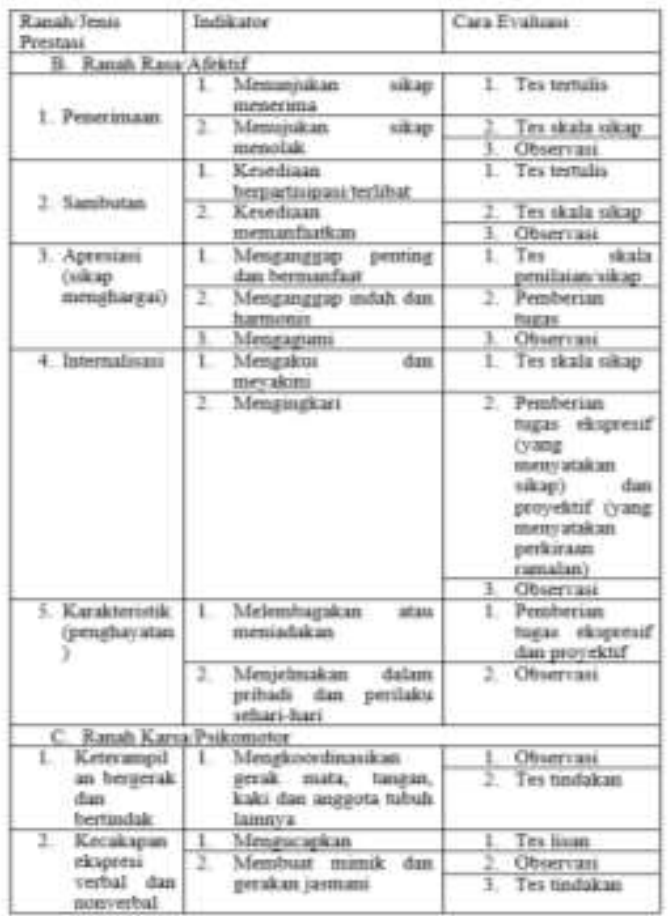

\section{B. Motivasi Belajar}

Sumber: Muhibbin Syah (2002)

\section{Pengertian Motivasi Belajar}

Motivasi dan belajar merupakan dua hal yang saling mempengaruhi. Belajar adalah perubahan tingkah laku secara relatif permanen dan secara potensial terjadi sebagai hasil praktik atau penguatan. Ada beberapa definisi motivasi, seperti yang diungkapkan. Menurut Hamzah B.Uno (2006) motivasi adalah dorongan yang ada dalam diri individu yang dapat menggerakkan seseorang itu untuk melakukan sesuatu.

\section{Indikator Motivasi Belajar}

Hal ini mempunyai peranan besar dalam keberhasilan seseorang dalam belajar. Indikator motivasi belajar dapat diklasifikasikan sebagai berikut:

a. Adanya hasrat dan keinginan berhasil;

b. Adanya dorongan dan kebutuhan dalam belajar;

c. Adanya harapan dan cita-cita masa depan;

d. Adanya penghargaan dalam belajar;

e. Adanya kegiatan yang menarik dalam belajar;

Adanya lingkungan belajar yang kondusif, sehingga memungkinkan seseorang mahasiswa dapat belajar dengan baik.

\section{Minat Belajar}

\section{Pengertian Minat Belajar}

Menurut M. Buchori dalam Ainamulyana (2017) pengertian minat adalah kesadaran seseorang, bahwa suatu objek, seseorang, suatu soal atau situasi mengandung sangkut paut dengan dirinya.

\section{Indikator Minat Belajar}

Djamarah dalam Ainamulyana (2017) mengungkapkan bahwa minat dapat diekspesikan anak didik melalui:

a. Memberikan perhatian yang lebih besar terhadap sesuatu yang diminatinya tanpa menghiraukan yang lain (fokus).

b. Pernyataan lebih menyukai sesuatu daripada yang lainnya. 
c. Partisipasi aktif dalam suatu kegiatan.

Minat diperoleh melalui suatu proses belajar yang timbul melalui proses mengamati suatu objek yang kemudian menghasilkan suatu penilaian-penilaian tertentu terhadap objek yang menimbulkan minat seseorang.

\section{Kesehatan Jasmani}

\section{Pengertian Kesehatan Jasmani}

Kesehatan Jasmani adalah kesanggupan tubuh untuk melakukan berbagai aktivitas dengan baik tanpa mengalami kelelahan yang berarti (Maxmanroe, 2019). Dan setelah melakukan aktivitas secara optimal, tubuh masih memiliki cadangan tenaga untuk dapat melakukan kegiatan lainnya.

\section{Indikator Kesehatan Jasmani}

Untuk mencapai kesegaran jasmani dibutuhkan beberapa komponen indikator yang harus dipenuhi. Beberapa komponen kesehatan jasmani tersebut adalah:

a. Kekuatan (Strength)

b. Daya Tahan (Endurance)

c. Daya Otot (Muscular Power)

d. Kecepatan (Speed)

e. Daya lentur (Flexibility)

f. Kelincahan (Agility)

g. Koordinasi (Coordination)

h. Keseimbangan (Balance)

i. Ketepatan (Accuracy)

j. Reaksi (Reaction)

\section{E. Pembimbing Akademik (PA)}

\section{Pengertian Pembimbing Akademik (PA)}

Dalam rangka membantu mahasiswa menyelesaian studinya. Perguruan Tinggi diharapkan dapat menyediakan Pembimbing Akademik. Pembimbing akademik adalah dosen yang ditunjuk dan diserahi tugas membimbing sekelompok mahasiswa yang bertujuan untuk membantu mahasiswa menyelesaikan studinya secepat dan seefisien mungkin sesuai dengan kondisi dan potensi individual mahasiswa, jadi indikator seorang pembimbing akademik adalah dosen tetap dalam institusi pendidikan tinggi (Abdu Aziz, 2013).

\section{Fungsi Pembimbing Akademik (PA)}

Beberapa fungsi pembimbing akademik yaitu:

a. Membantu mahasiswa menyusun rencana studi sejak semester pertama sampai mahasiswa itu selesai studi.

b. Memberikan pertimbangan tentang mata kuliah (wajib dan Pilihan) yang dapat diambil pada semester yang akan berlangsung kepada mahasiswa bimbingannya dengan memahami kebutuhan belajarnya.

c. Memberikan pertimbangan tentang banyaknya kredit yang dapat diambil pada semester yang akan berlangsung sesuai dengan keberhasilan studi pada semester sebelumnya dan menyatakan kesetujuannya dengan cara memvalidasi /menandatangani Formulir Rencana Studi (FRS).

d. Membantu mahasiswa menyalurkan minat dan bakatnya untuk meningkatkan kemampuan akademiknya.

e. Membantu mahasiswa memahami materi perkuliahan dan manfaat mempelajari ilmu yang diambilnya. 


\section{F. Lingkungan Sosial}

\section{Pengertian Lingkungan Sosial}

Lingkungan sosial, konteks sosial, konteks sosiokultural, atau milieu, adalah sesuatu hal yang didefinisikan sebagai suasana fisik atau suasana sosial dimana manusia hidup didalamnya, atau dimana sesuatu terjadi dan berkembang. Lingkungan sosial tersebut bisa berupa kebudayaan atau kultur yang diajarkan atau dialami oleh seorang individu, atau juga manusia dan institusi yang berinteraksi dengan individu tersebut (Barnett dan Casper dalam Dominique, 2012).

\section{Indikator Lingkungan Sosial}

Terkait dengan kesinambungan lingkungan sosial maka setidaknya terdapat empat komponen lingkungan sosial yang perlu diperhatikan (Purba). Keempat komponen tersebut ialah:

a. Pengelompokan sosial

b. Pranata sosial

c. Kebutuhan sosial

d. Penataan sosial

\section{METODOLOGI PENELITIAN}

Metodologi penelitian adalah keseluruhan proses yang dilakukan dalam penelitian guna mendapatkan data-data penelitian yang dibutuhkan serta cara menganalisis data penelitian, sehingga diperoleh fakta-fakta dan prinsip-prinsip hasil penelitian dengan sabar, hati-hati dan sistematis untuk mewujudkan kebenaran.

Metode penelitian yang digunakan adalah metode kuantitatif. Menurut Sugiyono (2016), "Metode kuantitatif dapat diartikan sebagai metode penelitian yang berlandaskan pada filsafat positivisme, digunakan untuk meneliti pada populasi atau sample tertentu, pengumpulan data menggunakan instrumen penelitian, analisis data bersifat kuantitatif/statistik, dengan tujuan untuk menguji hipotesis yang telah ditetapkan".

Desain penelitian merupakan bagian dari perencanaan penelitian yang menunjukan penelitian untuk melihat apakah penelitian yang direncanakan telah memiliki validitas internal dan validitas eksternal yang komprehensif. Berdasakan rumusan dan tujuan sebelumnya, metode penelitian yang digunakan penulis adalah metode deskriptif, yaitu yang mengungkapkan gambaran masalah yang terjadi pada saat penelitian ini berlangsung.

Yang dimaksud "Teknik sampling adalah merupakan teknik pengambilan sample, untuk menentukan sampel yang akan digunakan dalam penelitian" Sugiyono (2016), dalam penelitian ini penulis menggunakan metode simpel random sampling, dimana semua data yang di dapat dijadikan sampel.

\section{HASIL DAN PEMBAHASAN}

\section{A. Karakteristik Responden}

Tabel 4.1

Hasil Output Jenis Kelamin Responden Jenis Kelamin

\begin{tabular}{|ll|r|r|r|r|}
\hline & \multicolumn{1}{|c|}{ Frequency } & Percent & Valid Percent & \multicolumn{2}{c|}{$\begin{array}{c}\text { Cumulative } \\
\text { Percent }\end{array}$} \\
\hline \multirow{3}{*}{ Valid Laki-laki } & 113 & 35.1 & 35.1 & 35.1 \\
& Perempuan & 209 & 64.9 & 64.9 & 100.0 \\
& Total & 322 & 100.0 & 100.0 & \\
\hline
\end{tabular}

Sumber: Data Olahan Kuesioner 2019 
Dari tabel 4.1 dapat dijelaskan bahwa untuk responden berjeniskelamin laki-laki sebanyak 113 responden $35,1 \%$ dan untuk responden berjenis kelamin perempuan sebanyak 209 responden $64,9 \%$. Jadi kesimpulan bahwa responden berdasarkan jenis kelamin didominasi responden berjenis kelamin laki-laki.

\section{B. Analisa Deskriptif}

Analisa deskriptif adalah bagian dari statistik yang digunakan untuk menggambarkan atau mendeskripsikan data tanpa bermaksud menggeneralisir atau membuat kesimpulan instrumen variabel Prestasi Belajar $(Y)$ menjukkan total skor sebesar 13730 dan rata-rata skor 4,26 dan masuk kedalam rentang kategori Baik, serta skor jawaban Sangat Setuju (SS) sebesar 42,95\%, Setuju (S) 43,91\%, Ragu-Ragu (RR) sebesar 10,31\%, Tidak Setuju (TS) sebesar 2,24\% dan Sangat Tidak Setuju (STS) sebesar 0,59\%.

Variabel Prestasi Belajar ( $\mathrm{Y}$ ) yang harus ditingkatkan adalah pada instrumen no 6 yang mendapatkan skor rata-rata terendah sebesar 3,80. Pada instrumen ini agar dosen menanyakan IPK pada saat memulai perkuliahan awal semester agar dapat memotivasi mahasiswa/i bisa lebih berprestasi lagi.

\section{B. Uji Kualitas Data}

a. Uji Validitas Variabel Motivasi Belajar $\left(X_{1}\right)$

\section{Tabel 4.8}

Hasil Uji Validitas Motivasi Belajar $\left(\mathbf{X}_{1}\right)$

\begin{tabular}{|c|c|c|c|}
\hline No & $\begin{array}{c}\mathbf{R} \\
\text { Hitung }\end{array}$ & $\mathbf{R}_{\text {Tabel }}$ & Ket \\
\hline 1 & 0.621 & 0.113 & Valid \\
\hline 2 & 0.646 & 0.113 & Valid \\
\hline 3 & 0.669 & 0.113 & Valid \\
\hline 4 & 0.689 & 0.113 & Valid \\
\hline 5 & 0.717 & 0.113 & Valid \\
\hline 6 & 0.668 & 0.113 & Valid \\
\hline 7 & 0.411 & 0.113 & Valid \\
\hline 8 & 0.583 & 0.113 & Valid \\
\hline 9 & 0.749 & 0.113 & Valid \\
\hline 10 & 0.710 & 0.113 & Valid \\
\hline
\end{tabular}

\section{Sumber : Data Olahan Kuesioner 2019}

Berdasarkan tabel diatas dapat dilihat bahwa untuk masing-masing pernyataan pada variabel Motivasi Belajar $\left(\mathrm{X}_{1}\right)$ seluruh item terbukti valid, karena nilai $\mathrm{r}_{\text {hitung }}$ yang dihasilkan lebih besar dari pada nilai $r_{\text {tabel }}$ yang ada untuk $n=322$ yaitu 0,113 .

b. Uji Validitas Variabel Minat Belajar $\left(\mathbf{X}_{2}\right)$

\section{Tabel 4.9}

Hasil Uji Validitas Minat Belajar $\left(\mathbf{X}_{2}\right)$

\begin{tabular}{|c|c|c|c|}
\hline No & $\begin{array}{c}\mathbf{R} \\
\text { Hitung }\end{array}$ & $\mathbf{R}_{\text {Tabel }}$ & Ket \\
\hline 1 & 0.412 & 0.113 & Valid \\
\hline 2 & 0.469 & 0.113 & Valid \\
\hline 3 & 0.497 & 0.113 & Valid \\
\hline
\end{tabular}




\begin{tabular}{|c|c|c|c|}
\hline No & $\begin{array}{c}\mathbf{R} \\
\text { Hitung }\end{array}$ & $\mathbf{R}_{\text {Tabel }}$ & Ket \\
\hline 4 & 0.449 & 0.113 & Valid \\
\hline 5 & 0.537 & 0.113 & Valid \\
\hline 6 & 0.500 & 0.113 & Valid \\
\hline 7 & 0.564 & 0.113 & Valid \\
\hline 8 & 0.431 & 0.113 & Valid \\
\hline 9 & 0.416 & 0.113 & Valid \\
\hline 10 & 0.544 & 0.113 & Valid \\
\hline
\end{tabular}

\section{Sumber : Data Olahan Kuesioner 2019}

Berdasarkan tabel diatas dapat dilihat bahwa untuk masing-masing pernyataan pada variabel Minat Belajar $\left(\mathrm{X}_{2}\right)$ seluruh item terbukti valid, karena nilai $r_{\text {hitung }}$ yang dihasilkan lebih besar dari pada nilai $r_{\text {tabel }}$ yang ada untuk $n=322$ yaitu 0,113 .

c. Uji Validitas Variabel Kesehatan Jasmani $\left(X_{3}\right)$

Tabel 4.10

Hasil Uji Validitas Kesehatan Jasmani $\left(X_{3}\right)$

\begin{tabular}{|c|c|c|c|}
\hline No & $\begin{array}{c}\mathbf{R} \\
\text { Hitung }\end{array}$ & $\mathbf{R}_{\text {Tabel }}$ & Ket \\
\hline 1 & 0.726 & 0.113 & Valid \\
\hline 2 & 0.500 & 0.113 & Valid \\
\hline 3 & 0.494 & 0.113 & Valid \\
\hline 4 & 0.675 & 0.113 & Valid \\
\hline 5 & 0.697 & 0.113 & Valid \\
\hline 6 & 0.485 & 0.113 & Valid \\
\hline 7 & 0.299 & 0.113 & Valid \\
\hline 8 & 0.495 & 0.113 & Valid \\
\hline 9 & 0.607 & 0.113 & Valid \\
\hline 10 & 0.663 & 0.113 & Valid \\
\hline
\end{tabular}

Sumber : Data Olahan Kuesioner 2019

Berdasarkan tabel diatas dapat dilihat bahwa untuk masing-masing pernyataan pada variabel Kesehatan Jasmani $\left(X_{3}\right)$ seluruh item terbukti valid, karena nilai $r_{\text {hitung }}$ yang dihasilkan lebih besar dari pada nilai $r_{\text {tabel }}$ yang ada untuk $n=322$ yaitu 0,113.

d. Uji Validitas Variabel Pembimbing Akademik $\left(\mathrm{X}_{4}\right)$

Tabel 4.11

Hasil Uji Validitas Pembimbing Akademik $\left(\mathrm{X}_{4}\right)$

\begin{tabular}{|c|l|c|c|}
\hline No & $\mathbf{R}_{\text {Hitung }}$ & $\mathbf{R}_{\text {Tabel }}$ & Ket \\
\hline 1 & 0.772 & 0.113 & Valid \\
\hline 2 & 0.694 & 0.113 & Valid \\
\hline 3 & 0.712 & 0.113 & Valid \\
\hline 4 & 0.717 & 0.113 & Valid \\
\hline
\end{tabular}




\begin{tabular}{|c|l|c|c|}
\hline No & $\mathbf{R}_{\text {Hitung }}$ & $\mathbf{R}_{\text {Tabel }}$ & Ket \\
\hline 5 & 0.726 & 0.113 & Valid \\
\hline 6 & 0.736 & 0.113 & Valid \\
\hline 7 & 0.740 & 0.113 & Valid \\
\hline 8 & 0.718 & 0.113 & Valid \\
\hline 9 & 0.747 & 0.113 & Valid \\
\hline 10 & 0.677 & 0.113 & Valid \\
\hline
\end{tabular}

\section{Sumber : Data Olahan Kuesioner 2019}

Berdasarkan tabel diatas dapat dilihat bahwa untuk masing-masing pernyataan pada variabel Pembimbing Akademik $\left(\mathrm{X}_{4}\right)$ seluruh item terbukti valid, karena nilai $\mathrm{r}_{\text {hitung }}$ yang dihasilkan lebih besar dari pada nilai $r_{\text {tabel }}$ yang ada untuk $n=322$ yaitu 0,113.

e. Uji Validitas Variabel Lingkungan Sosial $\left(X_{5}\right)$

Tabel 4.12

Hasil Uji Validitas Lingkungan Sosial $\left(X_{5}\right)$

\begin{tabular}{|c|l|l|c|}
\hline No & $\mathbf{R}_{\text {Hitung }}$ & $\mathbf{R}_{\text {Tabel }}$ & Ket \\
\hline 1 & 0.581 & 0.113 & Valid \\
\hline 2 & 0.607 & 0.113 & Valid \\
\hline 3 & 0.699 & 0.113 & Valid \\
\hline 4 & 0.599 & 0.113 & Valid \\
\hline 5 & 0.668 & 0.113 & Valid \\
\hline 6 & 0.535 & 0.113 & Valid \\
\hline 7 & 0.496 & 0.113 & Valid \\
\hline 8 & 0.514 & 0.113 & Valid \\
\hline 9 & 0.509 & 0.113 & Valid \\
\hline 10 & 0.441 & 0.113 & Valid \\
\hline
\end{tabular}

Sumber : Data Olahan Kuesioner 2019

Berdasarkan tabel diatas dapat dilihat bahwa untuk masing-masing pernyataan pada variabel Lingkungan Sosial $\left(X_{5}\right)$ seluruh item terbukti valid, karena nilai $r_{\text {hitung }}$ yang dihasilkan lebih besar dari pada nilai $r_{\text {tabel }}$ yang ada untuk $n=322$ yaitu 0,113.

f. Uji Validitas Variabel Prestasi Belajar (Y)

Tabel 4.13

Hasil Uji Validitas Prestasi Belajar (Y)

\begin{tabular}{|c|c|c|c|}
\hline No & $\mathbf{R}_{\text {Hitung }}$ & $\mathbf{R}_{\text {Tabel }}$ & Ket \\
\hline 1 & 0.640 & 0.113 & Valid \\
\hline 2 & 0.605 & 0.113 & Valid \\
\hline 3 & 0.711 & 0.113 & Valid \\
\hline 4 & 0.608 & 0.113 & Valid \\
\hline 5 & 0.540 & 0.113 & Valid \\
\hline 6 & 0.771 & 0.113 & Valid \\
\hline
\end{tabular}




\begin{tabular}{|c|c|c|c|}
\hline No & $\mathbf{R}_{\text {Hitung }}$ & $\mathbf{R}_{\text {Tabel }}$ & Ket \\
\hline 7 & 0.720 & 0.113 & Valid \\
\hline 8 & 0.726 & 0.113 & Valid \\
\hline 9 & 0.716 & 0.113 & Valid \\
\hline 10 & 0.712 & 0.113 & Valid \\
\hline
\end{tabular}

Sumber : Data Olahan Kuesioner 2019

Berdasarkan tabel diatas dapat dilihat bahwa untuk masing-masing pernyataan pada variabel Prestasi belajar $(\mathrm{Y})$ seluruh item terbukti valid, karena nilai $\mathrm{r}_{\text {hitung }}$ yang dihasilkan lebih besar dari pada nilai $r_{\text {tabel }}$ yang ada untuk $n=322$ yaitu 0,113 .

g. Uji Reliabilitas Variabel Motivasi Belajar $\left(X_{1}\right)$

Tabel 4.14

Uji Reliabilitas Variabel Motivasi Belajar $\left(\mathbf{X}_{1}\right)$

Reliability Statistics

\begin{tabular}{|r|r|}
\hline $\begin{array}{c}\text { Cronbach's } \\
\text { Alpha }\end{array}$ & N of Items \\
\hline .848 & 10 \\
\hline
\end{tabular}

h. Uji Reliabilitas Variabel Minat Belajar $\left(X_{2}\right)$

Tabel 4.15

Uji Reliabilitas Variabel Minat Belajar $\left(X_{2}\right)$

Reliability Statistics

\begin{tabular}{|r|r|}
\hline $\begin{array}{c}\text { Cronbach's } \\
\text { Alpha }\end{array}$ & N of Items \\
\hline .601 & 10 \\
\hline
\end{tabular}

i. Uji Reliabilitas Variabel Kesehatan Jasmani $\left(\mathbf{X}_{3}\right)$

Tabel 4.16

Uji Reliabilitas Variabel Kesehatan Jasmani $\left(X_{3}\right)$

Reliability Statistics

\begin{tabular}{|r|r|}
\hline $\begin{array}{c}\text { Cronbach's } \\
\text { Alpha }\end{array}$ & N of Items \\
\hline .767 & 10 \\
\hline
\end{tabular}

j. Uji Reliabilitas Variabel Pembimbing Akademik $\left(X_{4}\right)$

Tabel 4.17

Uji Reliabilitas Variabel Pembimbing Akademik $\left(X_{4}\right)$

Reliability Statistics

\begin{tabular}{|r|r|}
\hline $\begin{array}{c}\text { Cronbach's } \\
\text { Alpha }\end{array}$ & N of Items \\
\hline .897 & 10 \\
\hline
\end{tabular}

k. Uji Reliabilitas Variabel Lingkungan Sosial $\left(\mathbf{X}_{5}\right)$

Tabel 4.18

Uji Reliabilitas Variabel Lingkungan Sosial $\left(X_{5}\right)$

Reliability Statistics

\begin{tabular}{|c|c|}
\hline $\begin{array}{c}\text { Cronbach's } \\
\text { Alpha }\end{array}$ & N of Items \\
\hline
\end{tabular}




\section{Uji Reliabilitas Variabel Prestasi Belajar (Y)}

.752

Tabel 4.19

Uji Reliabilitas Variabel Prestasi Belajar (Y)

Reliability Statistics

\begin{tabular}{|r|r|}
\hline $\begin{array}{c}\text { Cronbach's } \\
\text { Alpha }\end{array}$ & N of Items \\
\hline .867 & 10 \\
\hline
\end{tabular}

Dari tabel Output SPSS diatas dapat dilihat bahwa koefisien reliabilitas variabel $X_{1}, X_{2}$, $\mathrm{X}_{3}, \mathrm{X}_{4}, \mathrm{X}_{5}$ dan $\mathrm{Y}$ lebih besar dari 0,60 artinya hasil pengukuran semua variabel tetap konsisten dan dapat di percaya.

\section{Uji Asumsi Klasik}

Uji asumsi dasar/klasik biasanya digunakan untuk mengetahui pola dari varian suatu populasi (data). Apakah populasi atau data berdistribusi normal atau tidak, atau juga dapat digunakan untuk mengetahui apakah populasi mempunyai beberapa varian yang sama, serta untuk menguji kelinearitasan data.

a. Uji Normalitas

Tabel 4.20

Hasil Output Uji Normalitas Kolmogorov-Smirnov One-Sample Kolmogorov-Smirnov Test

\begin{tabular}{|ll|r|}
\hline & & \multicolumn{1}{|c|}{ RES_1 } \\
\hline Normal Parameters ${ }^{\mathrm{a}, 0}$ & Mean & 322 \\
& Std. Deviation & .0000000 \\
& Absolute & 3.35785079 \\
MostExtreme Differences & Positive & .038 \\
& Negative & .033 \\
Kolmogorov-Smirnov $Z$ & & -.038 \\
Asymp. Sig. (2-tailed) & & .673 \\
\hline
\end{tabular}

\section{a. Test distribution is Normal.}

\section{b. Calculatedfrom data.}

Dari hasil uji Normalitas dengan metode Kolmogorov-Smirnov di atas, diperoleh besarnya nilai Test Statistic Kolmogorov-Smirnov adalah 0,796 dan nilai Sig 0,550. Nilai signifikansi lebih besar dari 0,05 maka Ho diterima yang berarti data residual berdistribusi normal. 


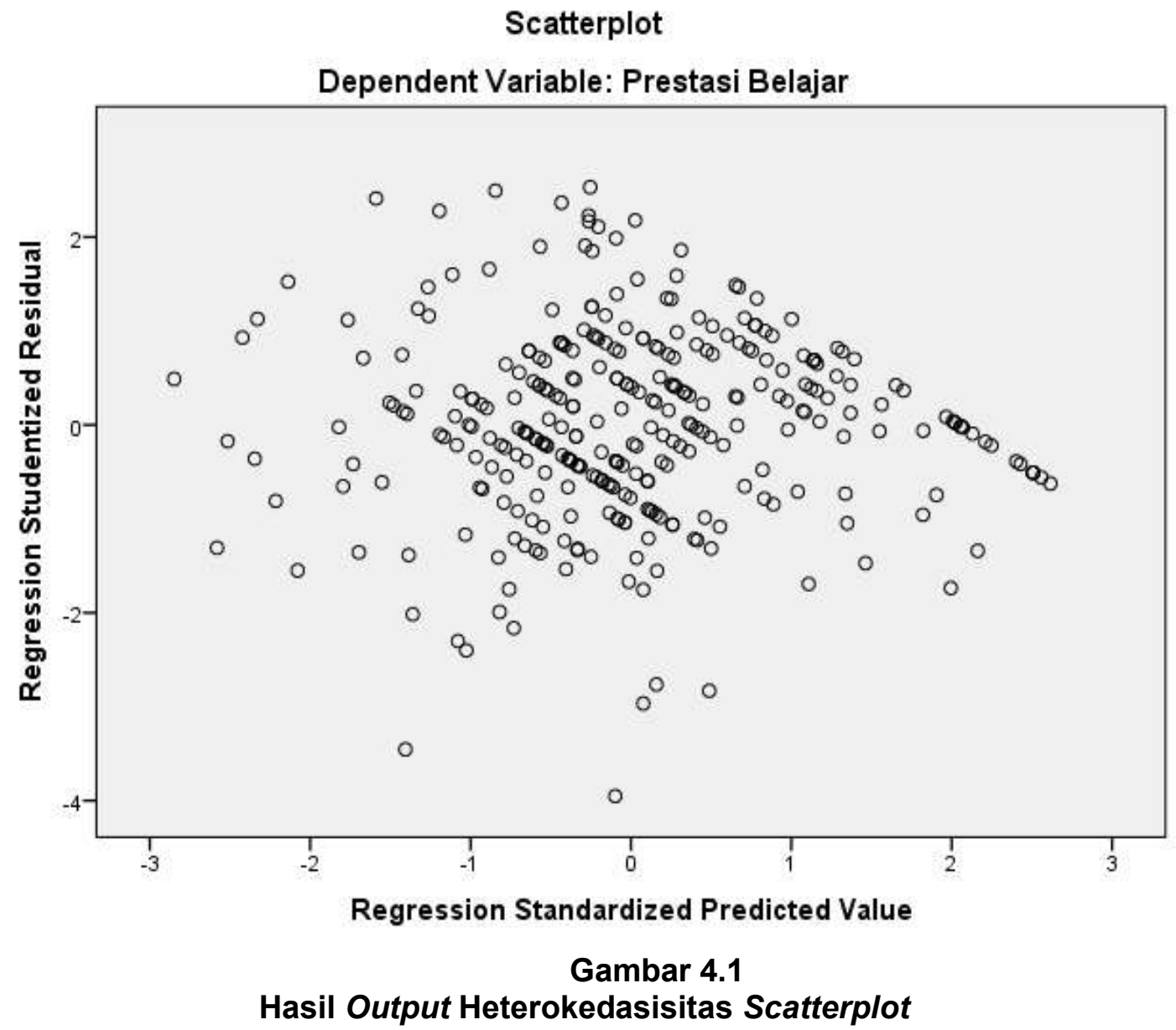

Dari gambar Scatterplot di atas menunjukkan bahwa titik-titik menyebar di atas dan dibawah angka 0 pada sumbu $Y$ serta penyebaran titik-titik data tidak berpola, maka dapat disimpulkan bahwa tidak terjadi heteroskedastisitas.

\section{c. Uji Multikolinieritas}

Tabel 4.21

Hasil Output SPSS 21 Pengujian Multikolinieritas

\begin{tabular}{|c|c|c|c|c|c|c|c|c|}
\hline \multicolumn{9}{|c|}{ Coefficients $^{3}$} \\
\hline \multirow{2}{*}{\multicolumn{2}{|c|}{ Model }} & \multicolumn{2}{|c|}{$\begin{array}{c}\text { Unstandardized } \\
\text { Coefficients }\end{array}$} & \multirow{2}{*}{$\begin{array}{c}\text { Standardized } \\
\text { Coefficients } \\
\text { Beta }\end{array}$} & \multirow[t]{2}{*}{$t$} & \multirow[t]{2}{*}{ Sig. } & \multicolumn{2}{|c|}{$\begin{array}{l}\text { Collinearity } \\
\text { Statistics }\end{array}$} \\
\hline & & $\mathrm{B}$ & $\begin{array}{l}\text { Std. } \\
\text { Error }\end{array}$ & & & & Tolerance & VIF \\
\hline \multirow{9}{*}{1} & (Constant) & 3.254 & 2.231 & & 1.458 & .146 & & \\
\hline & Motivasi Belajar & .535 & .066 & .439 & 8.109 & .000 & .502 & 1.993 \\
\hline & Minat Belajar & -.028 & .062 & -.021 & -.444 & .658 & .651 & 1.535 \\
\hline & Kesehatan & .147 & .050 & 143 & 2.969 & .003 & .635 & 1.574 \\
\hline & Jasmani & & & & & & & \\
\hline & Pembimbing & .163 & .057 & .155 & 2.864 & .004 & .502 & 1.992 \\
\hline & Akademik & & & & & & & \\
\hline & Lingkungan & .152 & .054 & .150 & 2.835 & .005 & .528 & 1.893 \\
\hline & Sosial & & & & & & & \\
\hline
\end{tabular}

a. DependentVariable: Prestasi Belajar 
Dari tabel di atas menunjukkan bahwa, dari masing-masing variabel nilai Tolerance dan VIF, terlihat tidak ada nilai Toleransi di bawah 0,10. Begitu pula dengan nilai VIF tidak ada yang diatas 10 . Dengan menggunakan parameter ini, tidak terbukti terjadi multikolinieritas.

d. Uji Autokorelasi

Tabel 4.22

Hasil Output SPSS 21 Pengujian Autokorelasi

\begin{tabular}{|l|r|r|r|r|r|}
\hline Model & \multicolumn{1}{|c|}{ Model Summary $^{\mathrm{b}}$} & R Square & Adjusted R Square & $\begin{array}{c}\text { Std. Error of the } \\
\text { Estimate }\end{array}$ & Durbin-Watson \\
\hline 1 & $.732^{3}$ & .535 & .528 & 3.384 & 1.901 \\
\hline
\end{tabular}

a. Predictors: (Constant), Lingkungan Sosial, Minat Belajar, Kesehatan Jasmani, Pembimbing

Akademik, Motivasi Belajar

b. DependentVariable: PrestasiBelajar

Nilai Durbin sebesar 1,901 akan dibandingkan dengan nilai tabel Durbin Watson dengan signifikansi $5 \%$ jumlah sampel 322 responden dan jumlah variabel bebas (independen) $5(\mathrm{~K}=5)$. Hasil nilai DU dan DL yang didapatkan dari tabel Durbin Watson adalah :

$\mathrm{DL}=1,7176$ dan $\mathrm{DU}=1,8199$.

Berdasarkan hasil pengambilan keputusan berada pada du $<\mathrm{d}<4$-du $(1,8199<$ $1,901<2,099$ ). Oleh karena nilai DW (Durbin Watson) sebesar 1,901 lebih besar dari batas atas (DU) 1,8199 dan kurang dari 2,099 ( 4-du), maka dapat disimpulkan bahwa hasil penelitian menyatakan tidak ada autokorelasi positif dan negatif atau dapat disimpulkan bahwa tidak terdapat autokorelasi.

\section{Uji Regresi Linear}

Analisis regresi linier digunakan oleh peneliti bila peneliti bermaksud meramalkan bagaimana keadaan (naik turunnya) variabel dependen (kriterium), bila ada satu variabel independen sebagai predictor dimanipulasi (dinaik turunkan nilainya).

a. Uji Regresi Linear Sederhana Sederhana Motivasi Belajar $\left(\mathbf{X}_{1}\right)$ Terhadap Prestasi Belajar (Y)

Tabel 4.23

Output Regresi Linear Sederhana Motivasi Belajar $\left(\mathrm{X}_{1}\right)$ Terhadap Prestasi Belajar $(\mathrm{Y})$

Coefficients $^{\mathrm{a}}$

\begin{tabular}{|rl|r|r|r|r|r|}
\hline \multicolumn{2}{|c|}{ Model } & \multicolumn{2}{|l|}{ Unstandardized Coefficients } & $\begin{array}{c}\text { Standardized } \\
\text { Coefficients }\end{array}$ & \multirow{2}{*}{$\mathrm{t}$} & Sig. \\
\cline { 2 - 5 } & \multicolumn{1}{|c|}{$\mathrm{B}$} & Std. Error & \multicolumn{1}{c|}{ Beta } & & \\
\hline \multirow{2}{*}{1} & 7.237 & 2.139 & & 3.383 & .001 \\
& (Constant) & .829 & .050 & .681 & 16.625 & .000 \\
\hline
\end{tabular}

a. Dependent Variable: Prestasi Belajar

Berdasarkan tabel Output di atas dapat dijelaskan bahwa, persamaan regesi linear sederhana $Y=a+b(x)$ adalah $Y=7,237+0,829\left(x_{1}\right)$. Persaman regesi ini dapat disimpulkan bahwa, terdapat pengaruh positif antara Motivasi Belajar $\left(X_{1}\right)$ Terhadap Prestasi Belajar (Y). 
b. Uji Regresi Linear Sederhana Sederhana Minat Belajar $\left(\mathrm{X}_{2}\right)$ Terhadap Prestasi Belajar (Y)

Tabel 4.24

Output Regresi Linear Sederhana

Minat Belajar $\left(\mathrm{X}_{2}\right)$ Terhadap Prestasi Belajar $(\mathrm{Y})$

Coefficients $^{3}$

\begin{tabular}{|c|c|c|c|c|c|c|}
\hline \multirow{2}{*}{\multicolumn{2}{|c|}{ Model }} & \multicolumn{2}{|c|}{ Unstandardized Coefficients } & \multirow{2}{*}{$\begin{array}{c}\begin{array}{c}\text { Standardized } \\
\text { Coefficients }\end{array} \\
\text { Beta } \\
\end{array}$} & \multirow[t]{2}{*}{$t$} & \multirow[t]{2}{*}{ Sig. } \\
\hline & & B & Std. Error & & & \\
\hline \multirow{2}{*}{1} & (Constant) & 23.391 & 2.392 & & 9.778 & .000 \\
\hline & Minat Belajar & .540 & .067 & .412 & 8.091 & .000 \\
\hline
\end{tabular}

a. Dependent Variable:Prestasi Belajar

Berdasarkan tabel Output di atas dapat dijelaskan bahwa, persamaan regesi linear sederhana $Y=a+b(x)$ adalah $Y=23,391+0,540\left(x_{2}\right)$. Persaman regresi ini dapat disimpulkan bahwa, terdapat pengaruh positif antara Minat Belajar $\left(\mathrm{X}_{2}\right)$ Terhadap Prestasi Belajar (Y).

c. Uji Regresi Linear Sederhana Sederhana Kesehatan Jasmani $\left(\mathbf{X}_{3}\right)$ Terhadap Prestasi Belajar (Y)

Tabel 4.25

Output Regresi Linear Sederhana

Kesehatan Jasmani $\left(\mathrm{X}_{3}\right)$ Terhadap Prestasi Belajar $(\mathrm{Y})$

Coefficients $^{\mathrm{a}}$

\begin{tabular}{|c|c|c|c|c|c|c|}
\hline \multirow{2}{*}{\multicolumn{2}{|c|}{ Model }} & \multicolumn{2}{|c|}{ Unstandardized Coefficients } & \multirow{2}{*}{$\begin{array}{c}\text { Standardized } \\
\text { Coefficients } \\
\text { Beta }\end{array}$} & \multirow[t]{2}{*}{$\mathrm{t}$} & \multirow[t]{2}{*}{ Sig. } \\
\hline & & $\mathrm{B}$ & Std. Error & & & \\
\hline \multirow{2}{*}{1} & (Constant) & 24.004 & 1.810 & & 13.260 & .000 \\
\hline & Kesehatan Jasmani & .518 & .050 & .502 & 10.384 & .000 \\
\hline
\end{tabular}

a. Dependent Variable: Prestasi Belajar

Berdasarkan tabel Output di atas dapat dijelaskan bahwa, persamaan regesi linear sederhana $Y=a+b(x)$ adalah $Y=24,004+0,518\left(x_{3}\right)$. Persaman regresi ini dapat disimpulkan bahwa, terdapat pengaruh positif antara Kesehatan Jasmani $\left(\mathrm{X}_{3}\right)$ Terhadap Prestasi Belajar (Y).

d. Uji Regresi Linear Sederhana Sederhana Pembimbing Akademik $\left(\mathrm{X}_{4}\right)$ Terhadap Prestasi Belajar (Y)

Tabel 4.26

Output Regresi Linear Sederhana

Pembimbing Akademik $\left(\mathrm{X}_{4}\right)$ Terhadap Prestasi Belajar $(\mathrm{Y})$

Coefficients $^{3}$

\begin{tabular}{|c|c|c|c|c|c|c|}
\hline \multirow{2}{*}{\multicolumn{2}{|c|}{ Model }} & \multicolumn{2}{|c|}{$\begin{array}{c}\text { Unstandardized } \\
\text { Coefficients }\end{array}$} & \multirow{2}{*}{$\begin{array}{c}\text { Standardized } \\
\text { Coefficients } \\
\text { Beta } \\
\end{array}$} & \multirow[t]{2}{*}{$\mathrm{t}$} & \multirow[t]{2}{*}{ Sig. } \\
\hline & & $B$ & Std. Error & & & \\
\hline & (Constant) & 17.915 & 1.957 & & 9.155 & .000 \\
\hline 1 & $\begin{array}{l}\text { Pembimbing } \\
\text { Akademik }\end{array}$ & .608 & .048 & .579 & 12.720 & .000 \\
\hline
\end{tabular}

a. Dependent Variable: Prestasi Belajar 
Berdasarkan tabel Output di atas dapat dijelaskan bahwa, persamaan regesi linear sederhana $Y=a+b(x)$ adalah $Y=17,915+0,608\left(x_{4}\right)$. Persaman regesi ini dapat disimpulkan bahwa, terdapat pengaruh positif antara Pembimbing Akademik $\left(\mathrm{X}_{4}\right)$ Terhadap Prestasi Belajar (Y).

e. Uji Regresi Linear Sederhana Sederhana Lingkungan Sosial $\left(X_{5}\right)$ Terhadap Prestasi Belajar (Y)

Tabel 4.27

Output Regresi Linear Sederhana Lingkungan Sosial $\left(\mathrm{X}_{5}\right)$ Terhadap Prestasi Belajar $(\mathrm{Y})$

Coefficients $^{B}$

\begin{tabular}{|ll|r|r|r|c|c|}
\hline \multicolumn{2}{|l|}{ Model } & \multicolumn{2}{|l|}{ Unstandardized Coefficients } & $\begin{array}{c}\text { Standardized } \\
\text { Coefficients }\end{array}$ & \multirow{2}{*}{$\mathrm{t}$} & \multirow{2}{*}{ Sig. } \\
\cline { 2 - 5 } & \multicolumn{1}{|c|}{$\mathrm{B}$} & \multicolumn{1}{c|}{ Std. Error } & \multicolumn{1}{c|}{ Beta } & & \\
\hline \multirow{2}{*}{$1 \quad$} & 21.617 & 1.758 & & 12.293 & .000 \\
& (Constant) & .567 & .047 & .559 & 12.058 & .000 \\
\hline
\end{tabular}

a. Dependent Variable: Prestasi Belajar

Berdasarkan tabel Output di atas dapat dijelaskan bahwa, persamaan regesi linear sederhana $Y=a+b(x)$ adalah $Y=21,617+0,567\left(x_{5}\right)$. Persaman regresi ini dapat disimpulkan bahwa, terdapat pengaruh positif antara Lingkungan Sosial $\left(X_{5}\right)$ Terhadap Prestasi Belajar (Y).

\section{f. Uji Regresi Linear Berganda}

Tabel 4.28

Output Regresi Linear Berganda

Motivasi Belajar $\left(X_{1}\right)$, Minat Belajar $\left(X_{2}\right)$, Kesehatan Jasmani $\left(X_{3}\right)$, Pembimbing Akademik $\left(X_{4}\right)$, dan Lingkungan Sosial $\left(X_{5}\right)$ Terhadap Prestasi Belajar $(Y)$ Coefficients $^{\mathrm{a}}$

\begin{tabular}{|c|c|c|c|c|c|c|c|c|}
\hline \multirow{2}{*}{\multicolumn{2}{|c|}{ Model }} & \multicolumn{2}{|c|}{$\begin{array}{c}\text { Unstandardized } \\
\text { Coefficients }\end{array}$} & \multirow{2}{*}{$\begin{array}{l}\text { Standardized } \\
\text { Coefficients } \\
\text { Beta }\end{array}$} & \multirow[t]{2}{*}{$\mathrm{T}$} & \multirow[t]{2}{*}{ Sig. } & \multicolumn{2}{|c|}{$\begin{array}{c}\text { Collinearity } \\
\text { Statistics }\end{array}$} \\
\hline & & B & $\begin{array}{l}\text { Std. } \\
\text { Error }\end{array}$ & & & & Tolerance & VIF \\
\hline \multirow{9}{*}{1} & (Constant) & 3.254 & 2.231 & & 1.458 & .146 & & \\
\hline & Motivasi Belajar & .535 & .066 & .439 & 8.109 & .000 & .502 & 1.993 \\
\hline & MinatBelajar & -.028 & .062 & -.021 & -.444 & .658 & .651 & 1.535 \\
\hline & Kesehatan & .147 & .050 & .143 & 2.969 & .003 & .635 & 1.574 \\
\hline & Jasmani & & & & & & & \\
\hline & Pembimbing & .163 & .057 & .155 & 2.864 & .004 & .502 & 1.992 \\
\hline & Akademik & & & & & & & \\
\hline & Lingkungan & .152 & .054 & .150 & 2.835 & .005 & .528 & 1.893 \\
\hline & Sosial & & & & & & & \\
\hline
\end{tabular}

a. Dependent Variable: Prestasi Belajar

Berdasarkan tabel Output di atas dapat dijelaskan bahwa, persamaan regesi linear berganda $Y=a+b_{1} x_{1}+b_{2} x_{2}+b_{3} x_{3}+b_{4} x_{4}+b_{5} x_{5}$ adalah $Y=3,254+0,535\left(x_{1}\right)+\left(-0,028\left(x_{2}\right)\right)$ $+0,147\left(x_{3}\right)+0,163\left(x_{4}\right)+0,152\left(x_{5}\right)$. Persaman regresi ini dapat disimpulkan bahwa, terdapat pengaruh positif antara Motivasi Belajar $\left(\mathrm{X}_{1}\right)$, Minat Belajar $\left(\mathrm{X}_{2}\right)$, Kesehatan Jasmani $\left(X_{3}\right)$, Pembimbing Akademik $\left(X_{4}\right)$, dan Lingkungan Sosial $\left(X_{5}\right)$ Terhadap Prestasi Belajar $(Y)$. 
E. Uji Hipotesis

a. Uji Hipotesis Motivasi Belajar $\left(\mathrm{X}_{1}\right)$ Terhadap Prestasi Belajar $(\mathrm{Y})$

Tabel 4.29

Coefficients $^{\mathrm{a}}$

\begin{tabular}{|c|c|c|c|c|c|c|}
\hline \multirow[t]{2}{*}{ Model } & & \multicolumn{2}{|c|}{ Unstandardized Coefficients } & \multirow{2}{*}{$\begin{array}{c}\text { Standardized } \\
\text { Coefficients } \\
\text { Beta }\end{array}$} & \multirow[t]{2}{*}{$\mathrm{t}$} & \multirow{2}{*}{ Sig. } \\
\hline & & $\mathrm{B}$ & Std. Error & & & \\
\hline \multirow{2}{*}{1} & (Constant) & 7.237 & 2.139 & & 3.383 & .001 \\
\hline & Motivasi Belajar & .829 & .050 & .681 & 16.625 & .000 \\
\hline
\end{tabular}

a. Dependent Variable:Prestasi Belajar

Berdasarkan tabel Output Coefficients di atas dapat disimpulkan bahwa :

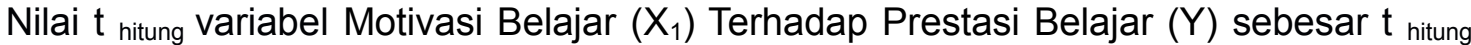
$16,625>t$ tabel 1,649983 atau nilai Sig 0,000 $<0,05$ maka $H_{0}$ di tolak dan $\mathrm{H}_{a}$ di terima artinya terdapat pengaruh positif dan signifikan antara Motivasi Belajar $\left(\mathrm{X}_{1}\right)$ Terhadap Prestasi Belajar (Y).

b. Uji Hipotesis Minat Belajar $\left(\mathrm{X}_{2}\right)$ Terhadap Prestasi Belajar $(\mathrm{Y})$

Tabel 4.30

Coefficients $^{\mathrm{a}}$

\begin{tabular}{|rl|r|r|r|r|r|}
\hline \multicolumn{2}{|l|}{ Model } & \multicolumn{2}{|c|}{ Unstandardized Coefficients } & \multicolumn{1}{c|}{$\begin{array}{c}\text { Standardized } \\
\text { Coefficients }\end{array}$} & \multirow{2}{*}{$\mathrm{t}$} & \multirow{2}{*}{ Sig. } \\
\cline { 3 - 6 } & \multicolumn{1}{|c|}{$\mathrm{B}$} & \multicolumn{1}{c|}{ Std. Error } & \multicolumn{1}{c|}{ Beta } & & \\
\hline \multirow{2}{*}{1} & 23.391 & 2.392 & & 9.778 & .000 \\
& (Constant) & .540 & .067 & .412 & 8.091 & .000 \\
\hline
\end{tabular}

a. DependentVariable: Prestasi Belajar

Berdasarkan tabel Output Coefficients di atas dapat disimpulkan bahwa:

Nilai $t$ hitung variabel Minat Belajar $\left(X_{2}\right)$ Terhadap Prestasi Belajar $(Y)$ sebesar $t$ hitung $8,091>t$ tabel 1,649983 atau nilai Sig $0,000<0,05$ maka $\mathrm{H}_{0}$ di tolak dan $\mathrm{H}_{\mathrm{a}}$ di terima artinya terdapat pengaruh positif dan signifikan antara Minat Belajar $\left(\mathrm{X}_{2}\right)$ Terhadap Prestasi Belajar ( $Y$ ).

c. Uji Hipotesis Kesehatan Jasmani $\left(\mathrm{X}_{3}\right)$ Terhadap Prestasi Belajar $(\mathrm{Y})$

Tabel 4.32

Coefficients $^{\mathrm{a}}$

\begin{tabular}{|c|c|c|c|c|c|c|}
\hline \multirow{2}{*}{\multicolumn{2}{|c|}{ Model }} & \multicolumn{2}{|c|}{ Unstandardized Coefficients } & \multirow{2}{*}{$\begin{array}{c}\text { Standardized } \\
\text { Coefficients } \\
\text { Beta } \\
\end{array}$} & \multirow[t]{2}{*}{$t$} & \multirow[t]{2}{*}{ Sig. } \\
\hline & & B & Std. Error & & & \\
\hline \multirow{2}{*}{1} & (Constant) & 24.004 & 1.810 & & 13.260 & .000 \\
\hline & Kesehatan Jasmani & .518 & .050 & .502 & 10.384 & .000 \\
\hline
\end{tabular}

a. Dependent Variable:Prestasi Belajar

Berdasarkan tabel Output Coefficients di atas dapat disimpulkan bahwa :

Nilai $t_{\text {hitung }}$ variabel Kesehatan Jasmani $\left(\mathrm{X}_{3}\right)$ Terhadap Prestasi Belajar $(\mathrm{Y})$ sebesar $\mathrm{t}$ hitung $10,384>t_{\text {tabel }} 1,649983$ atau nilai Sig $0,000<0,05$ maka $\mathrm{H}_{0}$ di tolak dan $\mathrm{H}_{\mathrm{a}}$ di terima artinya terdapat pengaruh positif dan signifikan antara Kesehatan Jasmani $\left(\mathrm{X}_{3}\right)$ Terhadap Prestasi Belajar (Y). 
d. Uji Hipotesis Pembimbing Akademik $\left(\mathrm{X}_{4}\right)$ Terhadap Prestasi Belajar $(\mathrm{Y})$

Tabel 4.29

Coefficients $^{\mathrm{a}}$

\begin{tabular}{|c|c|c|c|c|c|c|}
\hline \multirow{2}{*}{\multicolumn{2}{|c|}{ Model }} & \multicolumn{2}{|c|}{$\begin{array}{c}\text { Unstandardized } \\
\text { Coefficients }\end{array}$} & \multirow{2}{*}{$\begin{array}{c}\text { Standardized } \\
\text { Coefficients } \\
\text { Beta } \\
\end{array}$} & \multirow[t]{2}{*}{ t } & \multirow[t]{2}{*}{ Sig. } \\
\hline & & $\mathrm{B}$ & Std. Error & & & \\
\hline \multirow{3}{*}{1} & (Constant) & 17.915 & 1.957 & \multirow{3}{*}{.579} & 9.155 & .000 \\
\hline & Pembimbing & \multirow[t]{2}{*}{.608} & \multirow[t]{2}{*}{.048} & & \multirow[t]{2}{*}{12.720} & \multirow[t]{2}{*}{.000} \\
\hline & Akademik & & & & & \\
\hline
\end{tabular}

a. DependentVariable: Prestasi Belajar

Berdasarkan tabel Output Coefficients di atas dapat disimpulkan bahwa :

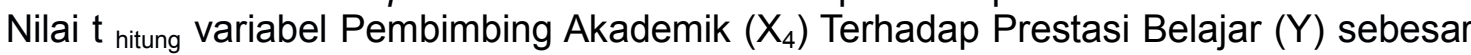
$\mathrm{t}$ hitung $12,720>\mathrm{t}$ tabel 1,649983 atau nilai Sig $0,000<0,05$ maka $\mathrm{H}_{0}$ di tolak dan $\mathrm{H}_{\mathrm{a}}$ di terima artinya terdapat pengaruh positif dan signifikan antara Pembimbing Akademik $\left(\mathrm{X}_{4}\right)$ Terhadap Prestasi Belajar (Y).

e. Uji Hipotesis Lingkungan Sosial $\left(\mathrm{X}_{5}\right)$ Terhadap Prestasi Belajar $(\mathrm{Y})$

Tabel 4.33

Coefficients $^{\mathrm{a}}$

\begin{tabular}{|c|c|c|c|c|c|c|}
\hline \multirow{2}{*}{\multicolumn{2}{|c|}{ Model }} & \multicolumn{2}{|c|}{ Unstandardized Coefficients } & \multirow{2}{*}{$\begin{array}{c}\text { Standardized } \\
\text { Coefficients } \\
\text { Beta }\end{array}$} & \multirow[t]{2}{*}{$t$} & \multirow[t]{2}{*}{ Sig. } \\
\hline & & $\mathrm{B}$ & Std. Error & & & \\
\hline \multirow{2}{*}{1} & (Constant) & 21.617 & 1.758 & & 12.293 & .000 \\
\hline & Lingkungan Sosial & .567 & .047 & .559 & 12.058 & .000 \\
\hline
\end{tabular}

a. Dependent Variable:Prestasi Belajar

Berdasarkan tabel Output Coefficients di atas dapat disimpulkan bahwa :

Nilai $\mathrm{t}_{\text {hitung }}$ variabel Lingkungan Sosial $\left(\mathrm{X}_{5}\right)$ Terhadap Prestasi Belajar $(\mathrm{Y})$ sebesar $\mathrm{t}_{\text {hitung }}$ $12,058>t$ tabel 1,649983 atau nilai Sig 0,000 $<0,05$ maka $\mathrm{H}_{0}$ di tolak dan $\mathrm{H}_{\mathrm{a}}$ di terima artinya terdapat pengaruh positif dan signifikan antara Lingkungan Sosial $\left(\mathrm{X}_{5}\right)$ Terhadap Prestasi Belajar (Y).

f. Uji Hipotesis Simultan Motivasi Belajar $\left(X_{1}\right)$, Minat Belajar $\left(X_{2}\right)$, Kesehatan Jasmani $\left(X_{3}\right)$, Pembimbing Akademik $\left(X_{4}\right)$, dan Lingkungan Sosial $\left(X_{5}\right)$ Terhadap Prestasi Belajar (Y)

Tabel 4.34

ANOVA $^{\mathrm{a}}$

\begin{tabular}{|rl|r|r|r|r|r|}
\hline Model & & Sum of Squares & \multicolumn{1}{c|}{ df } & Mean Square & F & \multicolumn{1}{c|}{ Sig. } \\
\hline \multirow{4}{*}{1} & Regression & 4168.884 & 5 & 833.777 & 72.796 & $.000^{\circ}$ \\
& Residual & 3619.327 & 316 & 11.454 & & \\
& Total & 7788.211 & 321 & & & \\
\hline
\end{tabular}

a. DependentVariable: Prestasi Belajar

b. Predictors: (Constant), Lingkungan Sosial, Minat Belajar, Kesehatan Jasmani, Pembimbing

Akademik, Motivasi Belajar

Melihat tabel Output di atas dapat dijelaskan bahwa, $\mathrm{F}_{\text {hitung }} 72,796>\mathrm{F}_{\text {tabel }} 2,25$ atau probabilitas Sig 0,000 $<0,05$ maka $\mathrm{H}_{0}$ di tolak dan $\mathrm{Ha}$ di terima artinya signifikan dengan 
demikian hipotesis yang diajukan menetapkan terdapat pengaruh positif dan signifikan secara bersama-sama antara Motivasi Belajar $\left(X_{1}\right)$, Minat Belajar $\left(X_{2}\right)$, Kesehatan Jasmani $\left(X_{3}\right)$, Pembimbing Akademik $\left(X_{4}\right)$, dan Lingkungan Sosial $\left(X_{5}\right)$ Terhadap Prestasi Belajar (Y) pada Yayasan Sasmita Jaya Universitas Pamulang.

\section{F. Koefisien Determinas}

Koefisien determinasi adalah kadar kontribusi variabel bebas terhadap variabel terikat. Koefisien determinasi dilambangkan $\mathrm{R}^{2}$.

a. Koefisien Determinasi Motivasi Belajar $\left(\mathbf{X}_{1}\right)$ Terhadap Prestasi Belajar $(\mathbf{Y})$

Hasil Output uji koefisien korelasi dan determinasi adalah sebagai berikut :

Tabel 4.35

Model Summary ${ }^{\circ}$

\begin{tabular}{|c|r|r|r|r|}
\hline Model & $\mathrm{R}$ & R Square & Adjusted R Square & $\begin{array}{c}\text { Std. Error of the } \\
\text { Estimate }\end{array}$ \\
\hline 1 & $.681^{\mathrm{a}}$ & .463 & .462 & 3.614 \\
\hline
\end{tabular}

\section{a. Predictors: (Constant), Motivasi Belajar \\ b. DependentVariable: Prestasi Belajar}

Dari tabel di atas dapat dijelaskan bahwa :

Nilai korelasi $R=0,681$ berada pada rentang $0,600-0,799$ dengan tingkat hubungan kuat, artinya Motivasi Belajar $\left(\mathrm{X}_{1}\right)$ memiliki tingkat hubungan kuat terhadap Prestasi Belajar $(Y)$.

Nilai $\mathrm{R}$ Square $=0,463$ dapat disimpulkan bahwa, Motivasi Belajar $\left(\mathrm{X}_{1}\right)$ memberikan kontribusi terhadap Prestasi Belajar (Y) sebesar 46,3\% dan sisanya 53,7\% dipengaruhi oleh faktor lain.

b. Koefisien Determinasi Minat Belajar $\left(\mathrm{X}_{2}\right)$ terhadap Prestasi Belajar $(\mathrm{Y})$

Hasil Output uji koefisien korelasi dan determinasi adalah sebagai berikut :

\section{Tabel 4.36}

Model Summary

\begin{tabular}{|c|r|r|r|r|}
\hline Model & $\mathrm{R}$ & R Square & Adjusted R Square & $\begin{array}{c}\text { Std. Error of the } \\
\text { Estimate }\end{array}$ \\
\hline 1 & $.412^{\mathrm{a}}$ & .170 & .167 & 4.495 \\
\hline
\end{tabular}

a. Predictors: (Constant), Minat Belajar

b. Dependent Variable: Prestasi Belajar

Dari tabel di atas dapat dijelaskan bahwa :

Nilai korelasi $R=0,412$ berada pada rentang $0,400-0,599$ dengan tingkat hubungan sedang, artinya Minat Belajar $\left(\mathrm{X}_{2}\right)$ memiliki tingkat hubungan sedang terhadap Prestasi Belajar $(Y)$.

Nilai $R$ Square $=0,170$ dapat disimpulkan bahwa, Minat Belajar $\left(X_{2}\right)$ memberikan kontribusi terhadap Prestasi Belajar $(Y)$ sebesar $17 \%$ dan sisanya $83 \%$ dipengaruhi oleh faktor lain. 
c. Koefisien Determinasi Kesehatan Jasmani $\left(\mathrm{X}_{3}\right)$ Terhadap Prestasi Belajar $(\mathrm{Y})$

Hasil Output uji koefisien korelasi dan determinasi adalah sebagai berikut :

Tabel 4.37

Model Summary ${ }^{\mathrm{b}}$

\begin{tabular}{|c|r|r|r|r|}
\hline Model & R & R Square & Adjusted R Square & $\begin{array}{c}\text { Std. Error of the } \\
\text { Estimate }\end{array}$ \\
\hline 1 & $.502^{\mathrm{a}}$ & .252 & .250 & 4.267 \\
\hline
\end{tabular}

a. Predictors: (Constant), Kesehatan Jasmani

b. DependentVariable: Prestasi Belajar

Dari tabel di atas dapat dijelaskan bahwa :

Nilai korelasi $R=0,502$ berada pada rentang $0,400-0,599$ dengan tingkat hubungan sedang, artinya Kesehatan Jasmani $\left(\mathrm{X}_{3}\right)$ memiliki tingkat hubungan sedang terhadap Prestasi Belajar $(\mathrm{Y})$.

Nilai $\mathrm{R}$ Square $=0,252$ dapat disimpulkan bahwa, Kesehatan Jasmani $\left(\mathrm{X}_{3}\right)$ memberikan kontribusi terhadap Prestasi Belajar $(\mathrm{Y})$ sebesar $25,2 \%$ dan sisanya $74,8 \%$ dipengaruhi oleh faktor lain.

d. Koefisien Determinasi Pembimbing Akademik $\left(\mathrm{X}_{4}\right)$ Terhadap Prestasi Belajar ( $\mathrm{Y}$ ) Hasil Output uji koefisien korelasi dan determinasi adalah sebagai berikut :

Tabel 4.38

Model Summary ${ }^{\mathrm{b}}$

\begin{tabular}{|c|r|r|r|r|}
\hline Model & $\mathrm{R}$ & R Square & Adjusted R Square & $\begin{array}{c}\text { Std. Error of the } \\
\text { Estimate }\end{array}$ \\
\hline 1 & $.579^{3}$ & .336 & .334 & 4.021 \\
\hline
\end{tabular}

a. Predictors: (Constant), Pembimbing Akademik

b. DependentVariable: Prestasi Belajar

Dari tabel di atas dapat dijelaskan bahwa :

Nilai korelasi $R=0,579$ berada pada rentang $0,400-0,599$ dengan tingkat hubungan sedang, artinya Pembimbing Akademik $\left(\mathrm{X}_{4}\right)$ memiliki tingkat hubungan sedang terhadap Prestasi Belajar (Y).

Nilai $\mathrm{R}$ Square $=0,336$ dapat disimpulkan bahwa, Pembimbing Akademik $\left(\mathrm{X}_{4}\right)$ memberikan kontribusi Terhadap Prestasi Belajar (Y) sebesar 33,6\% dan sisanya $66,4 \%$ dipengaruhi oleh faktor lain.

e. Koefisien Determinasi Lingkungan Sosial $\left(X_{5}\right)$ Terhadap Prestasi Belajar $(Y)$

Hasil Output uji koefisien korelasi dan determinasi adalah sebagai berikut :

\section{Tabel 4.39}

Model Summary ${ }^{b}$

\begin{tabular}{|c|r|r|r|r|}
\hline Model & $\mathrm{R}$ & R Square & Adjusted R Square & $\begin{array}{c}\text { Std. Error of the } \\
\text { Estimate }\end{array}$ \\
\hline 1 & $.559^{\mathrm{s}}$ & .312 & .310 & 4.091 \\
\hline
\end{tabular}

a. Predictors: (Constant), Lingkungan Sosial

b. DependentVariable:Prestasi Belajar

Dari tabel di atas dapat dijelaskan bahwa :

Nilai korelasi $R=0,559$ berada pada rentang $0,400-0,599$ dengan tingkat hubungan sedang, artinya Lingkungan Sosial $\left(X_{5}\right)$ memiliki tingkat hubungan sedang terhadap Prestasi Belajar (Y). 
Nilai $R$ Square $=0,312$ dapat disimpulkan bahwa, Lingkungan Sosial $\left(\mathrm{X}_{5}\right)$ memberikan kontribusi terhadap Prestasi Belajar (Y) sebesar 31,2\% dan sisanya 68,8\% dipengaruhi oleh faktor lain.

f. Uji Korelasi dan DeterminasiMotivasi Belajar $\left(X_{1}\right)$, Minat Belajar $\left(X_{2}\right)$, Kesehatan Jasmani $\left(X_{3}\right)$, Pembimbing Akademik $\left(X_{4}\right)$, dan Lingkungan Sosial $\left(X_{5}\right)$ Terhadap Prestasi Belajar (Y)

Hasil Output uji koefisien determinasi adalah sebagai berikut :

Tabel 4.32

Model Summary ${ }^{\mathrm{b}}$

\begin{tabular}{|c|r|r|r|r|r|}
\hline $\begin{array}{l}\text { Mod } \\
\text { el }\end{array}$ & $\mathrm{R}$ & $\begin{array}{c}\mathrm{R} \\
\text { Square }\end{array}$ & $\begin{array}{c}\text { Adjusted } \mathrm{R} \\
\text { Square }\end{array}$ & $\begin{array}{c}\text { Std. Error of } \\
\text { the Estimate }\end{array}$ & $\begin{array}{c}\text { Durbin- } \\
\text { Watson }\end{array}$ \\
\hline 1 & $.732^{\mathrm{a}}$ & .535 & .528 & 3.384 & 1.901 \\
\hline
\end{tabular}

a. Predictors: (Constant), Lingkungan Sosial, Minat Belajar, Kesehatan Jasmani, Pembimbing

Akademik, Motivasi Belajar

b. Dependent Variable: Prestasi Belajar

Dari tabel di atas dapat dijelaskan bahwa :

Nilai korelasi $R=0,732$ berada pada rentang $0,600-0,799$ dengan tingkat hubungan kuat, artinya Motivasi Belajar $\left(\mathrm{X}_{1}\right)$, Minat Belajar $\left(\mathrm{X}_{2}\right)$, Kesehatan Jasmani $\left(\mathrm{X}_{3}\right)$, Pembimbing Akademik $\left(X_{4}\right)$, dan Lingkungan Sosial $\left(X_{5}\right)$ memiliki tingkat hubungan kuat terhadap Prestasi Belajar (Y).

Nilai R Square $=0,535$ dapat disimpulkan bahwa, Motivasi Belajar $\left(X_{1}\right)$, Minat Belajar $\left(X_{2}\right)$, Kesehatan Jasmani $\left(X_{3}\right)$, Pembimbing Akademik $\left(X_{4}\right)$, dan Lingkungan Sosial $\left(X_{5}\right)$ memberikan kontribusi terhadap Prestasi Belajar $(Y)$ sebesar $53,5 \%$ dan sisanya $46,5 \%$ dipengaruhi oleh faktor lain.

\section{E. SIMPULAN}

Berdasarkan hasil penelitian menunjukkan bahwa, Terdapat pengaruh positif dan signifikan secara parsial antara Motivasi Belajar $\left(\mathrm{X}_{1}\right)$ terhadap Prestasi Belajar $(\mathrm{Y})$ pada Yayasan Sasmita Jaya Universitas Pamulang. Terdapat pengaruh positif dan signifikan secara secara parsial antara Minat Belajar $\left(\mathrm{X}_{2}\right)$ terhadap Prestasi Belajar $(\mathrm{Y})$ pada Yayasan Sasmita Jaya Universitas Pamulang. Terdapat pengaruh positif dan signifikan secara parsial antara Kesehatan Jasmani $\left(\mathrm{X}_{3}\right)$ terhadap Prestasi Belajar $(\mathrm{Y})$ pada Yayasan Sasmita Jaya Universitas Pamulang. Terdapat pengaruh positif dan signifikan secara secara parsial antara Pembimbing Akademik $\left(\mathrm{X}_{4}\right)$ terhadap Prestasi Belajar $(\mathrm{Y})$ pada Yayasan Sasmita Jaya Universitas Pamulang. Terdapat pengaruh positif dan signifikan secara secara parsial antara Lingkungan Sosial $\left(\mathrm{X}_{5}\right)$ terhadap Prestasi Belajar (Y) pada Yayasan Sasmita Jaya Universitas Pamulang. Terdapat pengaruh positif dan signifikan secara secara simultan antara Motivasi Belajar $\left(X_{1}\right)$, Minat Belajar $\left(X_{2}\right)$, Kesehatan Jasmani $\left(X_{3}\right)$, Pembimbing Akademik $\left(X_{4}\right)$, dan Lingkungan Sosial $\left(X_{5}\right)$ Terhadap Prestasi Belajar (Y) Yayasan Sasmita Jaya Universitas Pamulang. 


\section{DAFTAR PUSTAKA}

Ainamulyana. 2017. Minat Belajar. https://ainamulyana.blogspot.com/2012/02/minatbelajar.html. Diakses 25 Mei 2019.

Aziz, RZ Abdu. 2013. Peranan dan Fungsi Pembimbing Akademik. https://rzabdulaziz. wordpress.com/2013/05/23/peran-dan-fungsi-pembimbingakademik/. Diakses 16 Mei 2019.

B. uno, Hamzah. 2006. Orientasi Baru dalam Psikologi Pembelajaran. Jakarta: PT Bumi Aksara.

Dominique.

2012.

Pengertian

Lingkungan

Sosial. http://dominique122.blogspot.com/2015/05/pengertian-lingkungan-sosial-dan.html. Diakses 13 Mei 2019.

Hamalik, Oemar. 2001. Proses Belajar Mengajar. Jakarta : Bumi Aksara.

Lesmana, R., Sunardi, N., Kartono, K., Rudy, R., \& Sumiaty, R. Y. (2020). Implementasi Manajemen dalam Meningkatkan Minat Baca Warga Desa Cihambulu, Kec. Pabuaran, Kab. Subang, Jawa Barat. Jurnal Abdi Masyarakat Humanis, 1(2).

Maxmanroe. 2019. Pengertian Kebugaran Jasmani. https://www.maxmanroe.com/vid/umum/pengertian-kebugaran-jasmani.html. Diakses 19 Mei 2019.

Sunardi, N., Lesmana, R., \& Tumanggor, M. (2018). Implementasi Manajemen Dalam Meningkatkan Iman Dan Taqwa Masyarakat Dusun Panyeredan, Cimanggu, Cisalak, SubangJawa Barat. Jurnal Pengabdian Dharma Laksana, 1(1), 131-140.

Sugiyono. 2016. Metode Penelitian Kuantitatif Kualitataif dan Kombinasi (Mixed Methods). Bandung: Alfabeta.

Surya, Mohamad. 2004. Psikologi Pembelajaran dan Pengajaran. Bandung: Pustaka Bani Quraisy.

Syah, Muhibbin. 2008. Psikologi Pendidikan. Bandung. PT Remaja Rosdakarya. 